ARUNG SINGKANG (1700-1765):

HOW THE VICTORY OF WADJO' BEGAN

J. Noorduyn ${ }^{1}$

One of the most colorful figures in the history of Southwest Celebes is the man who was elected Chief King of the Buginese state of Wadjo' in 1737 and remained in this office until $1754 .^{2}$ His personal name was La Ma'dukelleng and his title is usually given as Arung (i.e., Prince of) Singkang, though he is also called Sultan of Pasir and Arung Peneki. He was probably born about 1700 and was of noble Wadjorese descent. When still a young man he was forced to flee his country, and he went to the east coast of Borneo, where there were already many Buginese settlers. Little is known about him during this time. He engaged in many activities and became known as a leader. He assembled a group of dedicated followers who manned his fleet of warships and in 1726 he conquered the towns of Kutai and Pasir. In 1737 he reappeared in Wadjo' with his own ships and troops and succeeded in rallying Wadjo' in a successful war against the mighty neighboring state of Bone. Within a few years he was able to bring most of the other Buginese states to his side, and in February 1739 an allied army under his command marched to Makasar with the avowed purpose of attacking the Dutch fort there.

Although they captured Goa, the Makasarese capital, they were unable to conclude successfully their bold expedition. Arung Singkang's following slowly began to dissolve at this critical juncture and his offensive power proved inadequate. Beginning on May 16, 1739, Arung Singkang launched four attacks on the fort but they were repulsed. Finally, on July 20, the Dutch troops defeated them decisively and put them to flight. Arung Singkang returned to Wadjo' to await the Dutch counterattack which came in January 1741 , but the Dutch were equally unsuccessful in their efforts to subdue Wadjo'. After some inconclusive battles and fruitless negotiations, they departed again on March 29. After that time Wadjo' remained almost completely outside Dutch influence for nearly a century and a half. Arung Singkang's

1. I am most grateful to the Netherlands Institute for Advanced Study at Wassenaar for providing the excellent facilities enabling me to finish this paper, and to Dr. L. Andaya for his generous assistance in improving the English expression in this paper. Any remaining errors are, of course, my own.

2. The most recent description of the former principality of Wadjo' and its institutions is "Hiérarchie et Pouvoir Traditionnels en Pays Wadjo'" by Christian Pelras in Archipe1, 1 (1971), pp. 169-191. older works are B. F. Matthes, Overde Wadjorezen met hum Handelsen Scheepswetboek (Makasar: P. Van Hartrop, 1869) and J. Noorduyn, Een achttiende-eeuwse kroniek van Wadjo' (The Hague: H. L. Smits, 1955). 
position in Wadjo' did not remain unchallenged, however. His term of office ended in civil war. After his retirement in 1754, he returned to the town of Peneki and to his private war against Bone. He died in 1765 .

The short Buginese story which is published below in English translation is concerned with a small part of Arung Singkang's career, viz. how he succeeded in going ashore in Wadjo' in $1737 .^{3}$ The importance of this story does not lie in its value as a historical source because there are other Buginese texts which describe the events of his time more accurately and in greater detail. ${ }^{4}$ These other sources usually restrict themselves to mentioning facts, dates, the course of official negotiations, etc. and do not contain opinions nor such unhistorical things as prophecies. ${ }^{5}$ Our short story, on the other hand, may give some insights into how the Wadjorese of that time viewed Arung Singkang and his exploits.

The central theme of the story and the climax to which it gradually leads is the idea that Arung Singkang was the man who liberated Wadjo', his native country. The Buginese term which the text here uses is derived from the same word which two centuries later became the slogan of the Indonesian revolution: maradeka (in Indonesian, merdeka). But, if concepts and events lying two centuries apart may be compared, there is one distinctive difference between the slogan of 1737 and the one used in 1945, viz. that Sabang and Merauke were still completely beyond the author's horizon, and, what is more, even Southwest Celebes as a totality did not come into his view. It is Wadjo'--a small part of a small region--whose victory is commemorated in the story. That Arung Singkang succeeded in liberating Wadjo' from the oppressive interventions of adjacent

3. The Buginese text is to be found in Ms. No. 126, pp, 1-14 of the loan collection of Makasarese and Buginese Manuscripts of the Netherlands Bible Society in the Leyden University Library, cf. J. Noorduyn, "Een Boeginees Geschriftje over Arung Singkang," Bijdragen tot de Taal-, Land- en Volkenkunde, CIX (1953), pp. 144-152.

4. The most detailed Buginese account is to be found in Cod. Or. 1923 VI, pp. 11-46 in the Leyden University Library. A summary of this text and some supplementary data from different chronicles are given in Noorduyn, Een achttiende-eeuwse, pp. 126-138. The story of Arung Singkang as it is contained in one of these chronicles has been published in full in Noorduyn, Een achttiende-eeuwse, pp. 278-299. Recently, some additional data about Arung Singkang's parentage and early years have been published by A. Zainal Abidin," S.H. in "Memperkenalkan beberapa Pahlawan Sulawesi Selatan Diperantauan (Istimewa La Maddukelleng Sultan Pasir)," Bingkisan Jajasan Kebudajaan Sulawesi Selatan \& Tenggara, I, No. 7 (1967), pp. 6-14.

5. Notes on Buginese and Makasarese historical 1iterature are to be found in: A.A. Cense, "Enige Aantekeningen over MakassaarsBoeginese Geschiedschrijving," Bijdragen tot de Taal-, Land-en Volkenkunde, CVII (1951), pp. 42-60; A.A. Cense, "01d Buginese and Macassarese Diaries," Bijdragen tot de Taal-, Land-en Volkenkunde, CXXII (1966), pp. 416-428; J. Noorduyn, "Origin of South Celebes Historical Writing," in Soedjatmoko, ed. "An Introduction to Indonesian Historiography (Ithaca: Cornel1 University Press, 1965), pp. 137-155. 
states is considered his great achievement, although this is but a small feat compared with the grand scheme which he had in mind and the ultimate object which he pursued but did not and could not attain at that time.

Under the strong leadership of Arung Singkang, Wadjo' came to occupy an unprecedented position of power in Southwest Celebes by bringing both large and small Buginese states under its banner through force or persuasion. In this process it naturally came into conflict with the Kingdom of Bone, which had become under Dutch patronage the most powerful state in Southwest Celebes after Makasar was conquered by the Dutch in 1669. The prominent position of Bone is the reason why Bone and its Queen Batari Todja figured as the principal opponents of Arung Singkang even before he had returned from Borneo to Wadjo'. The rulers of Bone made a sevenfold charge against him, tried to prevent him from returning to his country, and in vain laid an ambush for him when he did enter Wadjo'. It is this persistent but unsuccessful opposition of Bone which is stressed by the author of our story. The reader can almost sense the author's delight in recording the Queen of Bone's concession that Arung Singkang's retorts to her charges were irrefutable, even though they were in fact far from strong, if not completely beside the point. The author or his source even exaggerated Arung Singkang's offenses against Bone. According to our story he was accused of having killed a certain Topasarai, and he himself acknowledged this as a fact. It is known from other sources, however, that Topasarai was not killed but merely robbed. It seems as if the antagonism between Bone and Arung Singkang was deliberately overemphasized to accentuate clearly the latter's superiority. The same exultation in Arung Singkang's superiority can be sensed in the passage where the assembled princes of Bone are reported to admit that Arung Singkang's fleet was unrivalled and that it was senseless for Bone even to consider attacking him at sea.

Such small differences of fact or merely of emphasis contain certain clues as to the intentions of the author. Another detail in which the story differs from what actually happened is the sequence of events. For example, Bone's accusations were brought against Arung Singkang, contrary to what our story relates, after he and his troops went ashore and not before.

The true sequence of events is fairly well known from other Buginese sources. ${ }^{6}$ On his way back to Wadjo' Arung Singkang arrived off Palette, on the coast of Bone, on Apri1 8, 1737. There he was refused admittance to the river which he could have used to get to Wadjo' and therefore, went a few miles to the north, to Doping on the coast of Wadjo'. One of the messengers from Bone who came to see him in Doping was I Djakkolo', the Gellareng of Bontoala'. He arrived after Arung Singkang had been waiting off Doping for forty days. He informed Arung Singkang that Bone gave him permission to go ashore in Wadjo'. Two days later, on May 24, Arung Singkang went ashore and immediate1y proceeded to Singkang, where he stayed for thirty days. While he was in Singkang a conference of Bone and Wadjo' was held in Tosora, the capital of Wadjo', in which Bone brought seven accusations against Arung Singkang. The latter was invited to the conference and was given the opportunity to defend

6. Cf. the literature mentioned in note 4 . 
himself. He did so successfully and apparently was acquitted. After that, however, the Chief King of Wadjo' asked him not to continue staying in Singkang but to go to some place on the coast. He then went to Peneki, which lies to the south of Doping. He drove out the Bone troops which were garrisoned there and thus committed an open act of hostility. This was the immediate cause of the war between Wadjo' and Bone in which Arung Singkang soon came to play the leading role.

On examining this summary of events, one finds it difficult to believe that Arung Singkang, when he was in Doping, desisted from his plans (as our story wants us to believe), went away to the other side of the gulf, and only returned after a prophetic figure had urged him to do so. It is true, Arung Singkang could have gone away in the period of forty days in which he was lying off Doping, but he does not seem to have had a good reason for doing so since he was waiting in Doping to get permission to go ashore. The Chief King of Wadjo', it is true, did request him to leave. This request, however, was made only after Arung Singkang had entered Wadjo' and had a1ready been for some time in Singkang. Furthermore, he was not requested to leave Wadjo' but merely to stay nearer the coast.

It seems indisputable that the interesting story of Arung Singkang's meeting with the enigmatic "big scabby" prophet on the island of Padamarang is fiction rather than fact. This does not make the story less interesting, for it clearly expresses the author's belief that Arung Singkang's strong conviction was based on an auspicious prophecy and that his incredible acts were authorized by a supernatural sanction.

It is obvious that the prediction "you shall liberate Wadjo'," which according to our story was acted upon by Arung Singkang, is in fact a prophecy post eventum. This implies that the story itself was not written before Arung Singkang had really accomplished Wadjo's liberation, i.e., at least a few years after the events described in the story took place. It is quite possible that the differences of fact we noticed in the story are also to be ascribed to this distance of time. Nevertheless, there is evidence that these words and the special emphasis of the story were a reflection of contemporary public opinion. There clearly was a difference of opinion between Arung Singkang and his compatriots concerning the object of their enterprise, and in this matter our story seems to side with the latter rather than with Arung Singkang. There is no doubt that his ultimate aim was the termination of foreign dominance in Celebes, which is clearly shown by the words he is recorded to have spoken in a conference of Bone, Wadjo', and Soppeng in October 1737: "Wadjo' wishes that you, Bone, make the Dutch depart, because as long as they are here our countries will be in ruin." It is also certain that many, even among his closest associates, did not share these views, and only reluctantly followed him on his march to Makasar. Just before he departed for Makasar at the head of the combined armies of Bone, Wadjo', and Soppeng, the leaders of these countries decided against the expedition. It was only Arung Singkang's own forceful personality which finally persuaded them to go. "Return to your own countries," he is reported to have said to the leaders of the three countries. "I shall go myself to Makasar with my own troops." After these words they went with him. ${ }^{7}$ But

7. Cf. Noorduyn, Een achttiende-eeuwse, pp. 131, 133, 291. 
this fundamental difference of opinion about the common goal and about the means to attain it became one of the main reasons of his ultimate failure. Those who had not been totally persuaded in his convictions soon abandoned him when the decisive hour had come.

One may conclude that Arung Singkang was a fighter for freedom ahead of his time. In his eyes, the liberation of Wadjo' was not an end in itself but a necessary stage on the road to the real end. His contemporaries, however, expected less of him. They were satisfied when Wadjo' had gained its independence, and they honored the man who had liberated Wadjo' for what he did achieve. We do not know how many people held this opinion. The author of the following short story at least was among them, and, therefore, it is not difficult to understand why the theme of his story is "The Victory of Wadjo'."

\section{THE TEXT IN TRANSLATION}

This is how the victory of Wadjo' began.

When the King of Pasir was in Wadjo', the Queen of Bone sent a messenger to him. She sent the Gellareng of Bontoala' as the spokesman. The King of Pasir had been declared guilty of crimes committed far and wide, and so the Three Allied Countries had designated him as an evildoer. When it became known that the King of Pasir was in Wadjo', ways and means were contrived to drive him out of Wadjo'. In that state of affairs the Queen of Bone, the Arung Pitu, ${ }^{1}$ and a11 descendants of King Mappadjunnge arrived at a unanimous decision. After this the Gellareng of Bontoala' departed.

Upon his arrival the King of Pasir was informed that a messenger from Bone had come. The messenger entered briskly, dressed in a white Bone court dress and a black cap. He went quickly into the audience hall and sat down before the youthful King. To fulfill his mission of speaking for Her Majesty the Queen of Bone, he turned to the King of Pasir and said: "Her Majesty the Queen of Bone has sent me to say: The young Prince of Pasir has committed seven treansgressions against Bone and by so doing he neglected to maintain adat and failed to comply with its prescriptions. First, he killed Topasarai at Tobonio, 2 who belonged to the royal house of Bone. Secondly, he killed a messenger of Bone. Thirdly, he came to Mandar, made the Selimpao ${ }^{3}$ fight, placed his artillery in position, and frightened the King of Mandar, who is an ally of Bone. Fourthly, he passed by Balang-1ompo, ${ }^{4}$ which is a possession of Bone, and set fire to it.

1. The Arung Pitu (Seven Princes) were the highest advisory board in the kingdom of Bone.

2. Tobonio is a village on the southeast coast of Borneo.

3. Selimpao is apparently the name of Arung Singkang's fighting cock.

4. Balang-lompo and Balang-tja'di are small islands in the roads of Makasar. 
Fifthly, he went by Makasar and fired on the castle ${ }^{5}$ which belongs to a great friend of Bone. Sixthly, he entered the River Tjenrana ${ }^{6}$ aboard very strange ships and frightened the Arung of Bone, who is a woman. Seventhly, he gave orders to go to Kera ${ }^{7}$ and to kill La Selle', who was the son of Topalagai, together with two well-todo people and three from the lower class."

The Monarch of Pasir replied: "The words which Bone has spoken are true. But if you say that I killed Topasarai at Tobonio, I must reply that a Wadjorese man was killed by Bone people in Pasir. I sought for Bone people in the country of Pasir but there were none. Then it was said that there was a man from Bone at Tobonio. Therefore, I gave orders to kill him. I know very well that Topasarai belonged to the royal house of Bone, but I also know that the Three Allied Countries administer justice in a righteous way: A murderer is killed only when he and his victim are of equal birth. Well, the man who was killed by the Bone man was of noble blood in Wadjo'. Therefore, I killed Topasarai at Tobonio. You should acknowledge that we are on even terms now because he belonged to the royal house of Bone.

"When you say that I killed a messenger of Bone, I must reply that only some of my subjects who went fishing at sea had an encounter there. And when an encounter takes place at sea the law of the fishes is applied, namely: The vanquished is devoured.

"And, messenger of Bone, as to the fact that I stopped in Mandar, conquered the king, and made the Selimpao fight, I staked one thousand dollars against the king. I was afraid that the Selimpao would kill and that the king would still say that we were even. Therefore, I placed my guns in position because I reasoned that the king might claim that we were even in this cockfight. Being merchants, we try to be on our guard the best we can.

"And, Gellareng, as to my going to Balang-lompo and Balangtja'di, it was only some of my subjects who went ashore to get fresh water. They said to me: 'Lord, there are houses but no people.' I said: 'Set fire to them. They will be idol houses. May this redound to our merit in the hereafter.' at them.

"As to my passing by Makasar, since they fired at me I fired

"And, Gellareng, as to my entering the River Tjenrana, I did not see anybody change his ship. No pantjazeng entered the river, nor any padewakeng or padjala. How then could I have changed my ships? I had only binta', pantja'dja' and kanaikeng. ${ }^{8}$

5. This is Fort Rotterdam which was the seat of the Dutch East India Company in Makasar.

6. The River Tjenrana was the border river between Bone and Wadjo', but its mouth (with the town of Tjenrana) was in the possession of Bone.

7. Kera is a village in the north of Wadjo'.

8. The pantjaleng and padjala are types of fishing ships, the padewakeng is a commercial ship and the binta', pantja'dja and kanalkeng were used by pirates. 
"When you say, Gellareng, that at Kera I killed La Selle', the son of Topalagai, together with two we11-to-do people and three from the lower class, I must reply that Tjellaloa from Bone killed a man from Wadjo'. I was convinced that all would agree that he had to be revenged."

After that the Gellareng of Bontoala' returned to Bone. There the Arung Pitu happened to be assembled in the royal palace--sitting so close together that the knots of their headdresses touched each other-before Her Majesty the Divine Queen of Bone. The Queen of Bone turned to them and said: "In my opinion, the best thing to do is to send a messenger to the Chief King of Wadjo' because I think the arguments of the King of Pasir are irrefutable. If the Chief King should speak to his grandson, it would only be proper that the King of Pasir should concede."

The Arung Pitu respectfully payed their homage and said unanimous1y: "Whatever is the wish of our Divine Queen we will al1 execute."

Then the one who was sent to the spokesman departed. The noble Chiefs of Wadjo' happened to be assembled--sitting so close together that the knots of their headdresses touched each other--before the one who is called the pillar of the state, the Chief King of Wadjo'. The Chief King turned to the spokesman from Bone and said: "What is the message which the Divine Queen of Bone has entrusted you with?"

The one who was sent to be spokesman said in reply: "The Queen of Bone has sent me to say: Your grandson should not be allowed to remain in your country because it is very unpleasant for her to hear things about him, since he is guilty of a blood debt with regard to the Three Allied Countries."

Then the King of Pasir was summoned. The Chief King of Wadjo' said to him: "King of Pasir, you must leave Wadjo' because you have committed crimes towards the Allied Countries according to what Bone says."

The King of Pasir said: "I shall not go away if it is only Bone which says so."

Then the Chief King of Wadjo' said: "Wadjo' has concurred in this, King of Pasir. You must leave Wadjo'."

The King of Pasir said: "Only if you think that it is good for Wadjo' shall I agree to leave."

The Chief King said: "Yes, it is good for Wadjo' if you leave."

So the King of Pasir accepted that it was good for Wadjo' if he left. He then went away and again put out to sea. Near Palette he steered his course eastward for the isle of Padamarang. ${ }^{9}$ There in Padamarang he stopped and went ashore. He went to the river to take a bath. There he happened to meet a big scabby man.10 This man said

9. Padamarang is an island on the other side of the gulf of Bone, off the coast of Southeast Celebes.

10. In a story of the founding of Wadjo' a princess with a skin disease occurs and a similar figure is also known from Malay histories. In the present case the skin disease is of the type called ichthyosis, which was considered an "honorific" disease by the inhabitants of 
to the King of Pasir: "You must return. You will liberate Wadjo'."

The young Prince of Pasir quickly boarded his golden ship again in order to sail to Doping and to go ashore there.

Seven days after his arrival in Doping the inhabitants of the country of Bone knew about it. The Arung Pitu and the Queen of Bone also knew it. The Queen had the Arung Pitu summoned. When all of them were seated before the Queen, she turned to them and said: "Is it true, my Princes, that the King of Pasir has returned?"

The Arung Pitu unanimously confirmed it, saying: "It is true, my Lady. We are sure because he is at Doping about to go ashore."

The Queen of Bone said: "What is your opinion, Princes, about the landing of the King of Pasir at Doping?"

The Arung Pitu unanimously replied: "It would be senseless to engage in battle with the King of Pasir if it should be on ships since his ships are sailing forts with breastworks. In Bone there are no ships of this type."

The Queen of Bone said: "We11, my Princes, if he should go ashore, then you will be able to meet him in battle."

The Arung Pitu confirmed this. The Queen then said: "Gellareng of Bontoala', go to the King of Pasir and convey to him our favorable decision that he is allowed to go ashore."

Then the Gellareng of Bontoala' departed, accompanied by the Arung Pitu and over three thousand men. When they reached Lamarua ${ }^{11}$ the Bone army went into hiding there. The Gellareng of Bontoala' arrived at the ships of the King of Pasir. There were more than ten of them. The King of Pasir already saw the Gellareng of Bontoala' when the latter was still in the distance. He went quickly into his bedroom and dressed himself in a Bone court dress and a black cap.

When the envoy had taken his place, the young Prince, the King of Pasir, also entered the audience hali and sat down opposite the envoy. He turned to the envoy and said: "What is the message you have been sent to convey?"

The Gellareng answered: "Our Divine Queen of Bone has instructed me to go to the King of Pasir and say to him: I approve of your going ashore. When you go ashore a11 will be well with you and not bad; you will live and not die."

The young Prince of Pasir replied: "I am extremely glad of your words, my friend. But I say to you: If there is a liana obstructing me when I go ashore, I will cut it through."

Twice he repeated these words, that he would cut any liana obstructing him. The envoy agreed.

Then the young Prince tied a knot in the folds-of his waistband, turned to the envoy and said: "You may return. I certainly sha11 not fail to go ashore."

Southeast Celebes. Therefore, the prophetic figure in our story was presumably derived from the culture of Southeast Celebes.

11. Lamarua is situated on the coast of Wadjo', just south of Doping. 